\title{
Differentiation of Subpopulations of Human and Murine Hemopoietic Stem Cells by Hypotonic Lysis
}

\author{
Eero Niskanen and Martin J. Cline, Division of Hematology-Oncology, \\ Department of Medicine, University of California School of Medicine, \\ Los Angeles, California 90024
}

\begin{abstract}
A B S T RAC T Both human and mouse bone marrow contain subpopulations of hemopoietic stem cells that greatly vary in their resistance to water exposure: The cells forming erythroid colonies or bursts in methyl cellulose in vitro are most sensitive to hypotonic conditions and are destroyed within $60 \mathrm{~s}$ in the hypotonic milieu. The murine pluripotent stem cells assayed by the spleen colony technique, as well as both murine and human myeloid stem cells assayed by the plasma clot diffusion chamber technique, displayed intermediate sensitivity and were nearly completely eliminated by $120 \mathrm{~s}$ of exposure to water. Both human and mouse bone marrow stem cells producing myeloid colonies in agar are most resistant to hypotonic conditions. The addition of monocyte-macrophages and lymphoid cells to water-exposed mouse bone marrow cell populations to compensate for losses did not restore either erythroid or myeloid colony formation.
\end{abstract}

\section{INTRODUCTION}

Several techniques have been developed to separate murine pluripotent stem cells (colony-forming units, spleen [CFU-S] $)^{1}$ from committed myeloid stem cells (CFU, culture [CFU-C]). These methods have usually been based on differences in cell size $(1,2)$ or density $(3,4)$. Recently, Løvhaug et al. (5) have shown that CFU-S and CFU-C can also be distinguished from each other by their ability to resist hypotonic lysis. Exposure of a heterogeneous hematopoietic cell population to water depletes its CFU-S content much more rapidly than its CFU-C.

Dr. Cline is a recipient of an endowment from the Ambrose and Gladys Bowyer Foundation.

Received for publication 28 September 1978 and in revised form 25 September 1979.

${ }^{1}$ Abbreviations used in this paper: BFU-E, burst-forming units, erythroid; CFU-C, colony-forming units, culture; CFU-DG, CFU grown in diffusion chambers; CFU-E, CFU, erythroid; CFU-S, CFU, spleen.
This observation led us to apply the hypotonic lysis method to further characterize the cells that form colonies in the spleens of lethally irradiated mice (CFU-S), in plasma clots in diffusion chambers (CFU-DG) implanted in mice, in agar (CFU-C), and in methyl cellulose (CFU, erythroid [CFU-E] burst-forming units, erythroid [BFU-E]).

\section{METHODS}

Cell preparations. Female Swiss-Webster mice (Simonsen Laboratories, Gilroy, Calif.) weighing 25-39 g were used as donors of bone marrow cells, thymocytes, lymph node lymphocytes, and lung lavage cells, and as diffusion chamber recipients. $95 \%$ of the thymocytes were lysed by appropriate antitheta antisera, and $84 \%$ of the cells obtained by lung lavage were monocytes and macrophages. Cells were suspended in McCoy's 5A medium supplemented with $20 \%$ heat-inactivated fetal calf serum, penicillin, and streptomycin.

Bone marrow cell suspensions obtained from normal human volunteers were sedimented in 3\% dextran and also suspended in modified McCoy's medium. Viable cell count was determined by staining with trypan blue. Monocytes and macrophages were identified by "lipase" staining (4).

Hypotonic lysis. Cell suspensions were centrifuged at $1,500 \mathrm{rpm}$ for $10 \mathrm{~min}$ at room temperature. The medium was removed and the remaining cell button was suspended in double-distilled water for periods up to $5 \mathrm{~min}$. Isotonicity was restored by adding double-strength culture medium; subsequently, the numbers of CFU-S, CFU-DG, CFU-C, CFU-E, $B F U-E$, and morphologically recognizable cells were determined (5).

CFU-S assay. Mice used to assay CFU-S were pretreated with $750 \mathrm{R}$ total-body irradiation. Each mouse received $0.2 \mathrm{ml}$ of cell suspension (original suspension contained $4 \times 10^{5} / \mathrm{ml}$ ). They were killed $9 \mathrm{~d}$ later and their spleens were removed and fixed in Bouin's solution. The number of macroscopic colonies on the surface was determined (7).

Diffusion chamber assay. The plasma clot diffusion chamber technique used in this study is a modification (8) of the original described by Steinberg et al. (9). Diffusion chambers were prepared by gluing Millipore filters (Millipore Corp., Bedford, Mass.), pore size $0.22 \mu \mathrm{m}$, on both sides of a plastic ring. Each chamber was filled with $0.1 \mathrm{ml}$ of suspension (original contained $1 \times 10^{6}$ mouse or $4 \times 10^{6}$ human bone marrow cells $/ \mathrm{ml}$ ). After sealing, two chambers were implanted into the peritoneal cavity of each mouse. Recipients of diffusion chambers that contained human marrow were pretreated 
with $300 \mathrm{mg} / \mathrm{kg}$ cyclophosphamide $4 \mathrm{~h}$ before implantation. The plasma clot that had formed inside the chamber was fixed in 5\% glutaraldehyde and stained with benzidine-hematoxylin, dried, and made transparent by dipping in immersion oil. On microscopic examination, cell aggregates containing $>19$ myeloid cells were considered colonies.

Agar colony assay. A double-layer agar technique was used to assay CFU-C $(10,11)$. Mouse bone marrow cells were cultivated in the presence of colony-stimulating activity prepared from pregnant uteri and embryos as described (12). When human bone marrow cells were used as a target, colonystimulating activity was derived from human peripheral blood cells. Portions of the cell suspensions used for the diffusion chamber assay were plated.

Triplicate cultures were incubated in $7.5 \% \mathrm{CO}_{2}$, and the colonies were counted after 7 (mouse) or 10 (human) d.

Methyl cellulose technique. Mouse bone marrow (original contained $3 \times 10^{6} / \mathrm{ml}$ ) was cultured in Petri dishes using the methyl cellulose technique of Iscove et al. (13) as modified by Golde et al. (14). Human urinary erythropoietin was obtained from the Blood Resources Division of the National Institutes of Health, Bethesda, Md. Duplicate plates were incubated at $37^{\circ} \mathrm{C}$ in a humidified atmosphere of $7 \% \mathrm{CO}_{2}$ in air. On day 2, cell aggregates which contained more than seven erythroid cells were counted as colonies (CFU-E). On day 8 , aggregates of 40 cells or more were counted as BFU-E.

\section{RESULTS}

Exposure of murine bone marrow to water markedly decreased the number of viable cells during the 5-min period applied in this study. Total cell number changed only slightly (Fig. 1). Smears of the cell suspensions revealed that erythrocytes and their nucleated precursors disappeared within $30 \mathrm{~s}$. Both mononuclear cells and granulocytes representing all stages of maturation were seen in all samples. However, prolonged exposure to water distorted the cell morphology and made the differential counts unreliable.

Fig. 2 shows that the number of viable human mar-

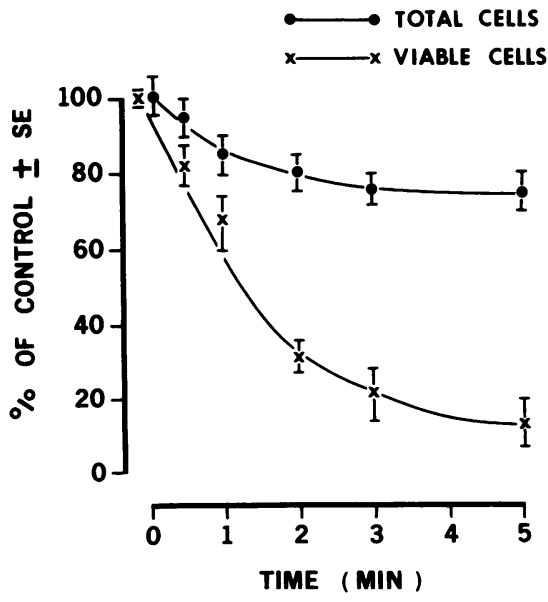

FigURE 1 Effect of hypotonic lysis on the number of mouse bone marrow cells. The cell concentration of the original sample was $1 \times 10^{6} / \mathrm{ml}$. Counts were obtained from five experiments.

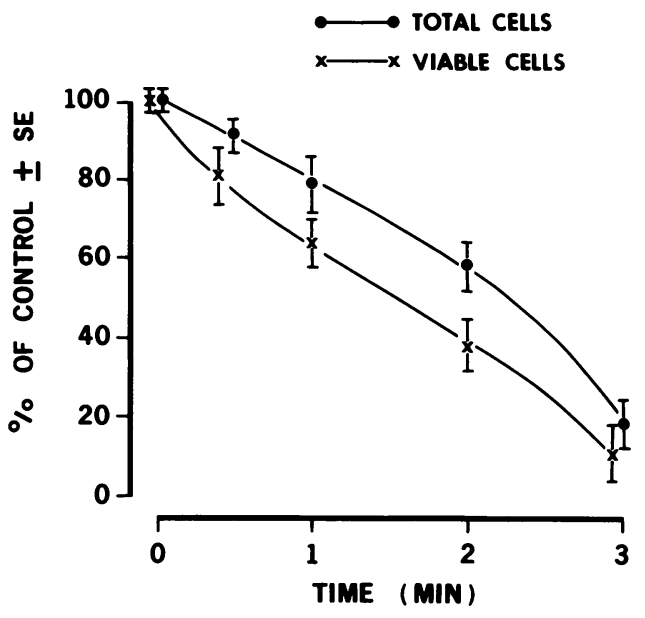

FIGURE 2 Effect of hypotonic lysis on the number of human bone marrow cells. The cell concentration of the original sample was $4 \times 10^{6} / \mathrm{ml}$. Counts were obtained from three experiments.

row cells decreased from the hypotonic milieu at the same rate as murine cells. The total number of human cells declined much faster than the mouse cells (Figs. 1 and 2).

The order of increasing susceptibility to water exposure was: $(a)$ the cells forming erythroid colonies (CFU-E); (b) the cells forming erythroid bursts (BFU-E); $(c)$ the cells forming colonies in the spleens of lethally irradiated mice (CFU-S); $(d)$ the cells forming myeloid colonies in diffusion chambers (CFU-DG); and $(e)$ the cells forming colonies in agar (CFU-C). The erythroid precursor, CFU-E, disappeared within $30 \mathrm{~s}$ (Fig. 3). At 1 min no BFU-E were detected (Fig. 3). At 2 min all CFU-S and 95\% of CFU-DG were eliminated. At the same time, the CFU-C number had declined only $20 \%$. An additional 3-min exposure caused a decrease of CFU-C to $10 \%$ of the initial count (Fig. 3).

As displayed in Fig. 3, a 3-min exposure of cells to hypotonicity resulted in elimination of CFU-DG and CFU-S, whereas over $40 \%$ of the CFU-C could be detected. In two experiments this cell suspension was concentrated by centrifuging and assayed for colony formation. The results (Table I) clearly indicate that the CFU-C number was directly related to the size of cell inoculum. Practically complete absence of CFU-S and CFU-DG is suggested by the very low colony yield even from the concentrates.

To determine whether decrease in colony formation was caused by direct effect on the precursor cell or mediated by action on a "helper" cell, suspensions of mouse cells subjected to hypotonic lysis for 1,3 , and $5 \mathrm{~min}$ were cocultured with monocyte-macrophages, lymph node lymphocytes, or thymocytes. Losses of mouse mononuclear phagocytes and lymphoid cells in the bone marrow were extrapolated from 


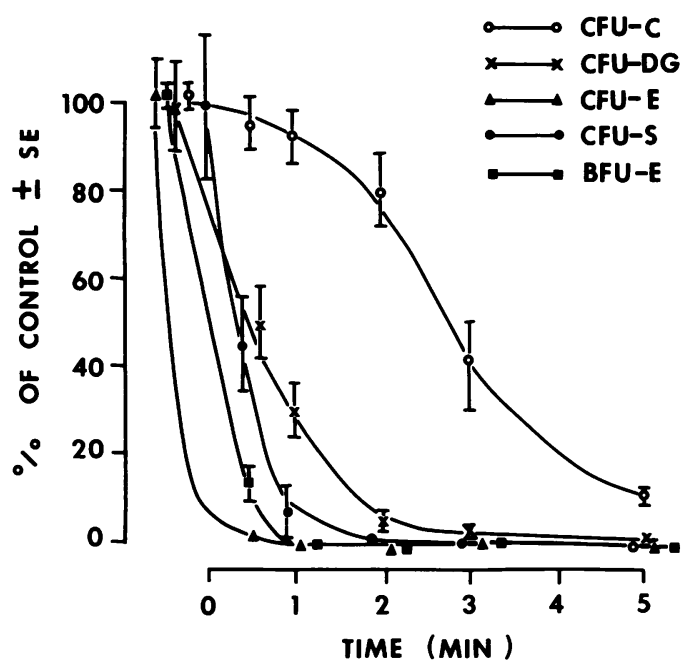

FIGURE 3 Effect of hypotonic lysis on different mouse colonyforming units. Counts were obtained from five experiments. The original samples contained on the average $110 \mathrm{CFU}-\mathrm{C}$, $198 \mathrm{CFU}-\mathrm{DG}, 260 \mathrm{CFU}-\mathrm{E}, 15 \mathrm{BFU}-\mathrm{E}$, and $18 \mathrm{CFU}-\mathrm{S} / 1 \times 10^{5}$ cells. Each point is an average of 9-24 observations.

the curves presented in Fig. 4. The normal bone marrow of the mice used in these experiments contained on the average $25 \%$ lymphoid cells, $4.5 \%$ theta-sensitive cells, ${ }^{2}$ and $0.4 \%$ monocytoid cells. The viable thymocyte count decreased at the same speed as in lymphocytes. Addition of these potential helper cells did not augment CFU-S, CFU-DG, CFU-C, BFU-E, or CFU-E numbers after lysis.

CFU-DG from human marrow also displayed higher sensitivity to hypotonic treatment than CFU-C. After 2 min of exposure to water the CFU-DG and CFU-C numbers has decreased to 1 and $64 \%$ of their original numbers, respectively (Fig. 5). Comparison of Figs. 3 and 5 shows that the human $\mathrm{CFU}-\mathrm{C}$ were more easily destroyed than the murine CFU-C.

As a result of lysis, cell debris inseparable from the viable cells is left in the medium. Because this might affect the plating efficiency, we added normal human or mouse bone marrow cell suspensions to tubes that contained a button of debris obtained by $15-\min \mathrm{H}_{2} \mathrm{O}$ lysis of bone marrow cells and assayed the mixture for CFU-S, CFU-DG, CFU-C, BFU-E, and CFU-E numbers. No significant effect was observed.

\section{DISCUSSION}

Our experimental observations indicate that the tolerance of hypotonicity of different populations of bone marrow differentiated cells and stem cell subpopulations differs. The most sensitive cells are the mature

${ }^{2}$ Niskanen, E., R. Ashman, and M. J. Cline. Unpublished data.
TABLE I

Colony Formation from Mouse Bone Marrow Cells Exposed to $\mathrm{H}_{2} \mathrm{O}$ for $3 \mathrm{~min}$

\begin{tabular}{crcc}
\hline $\begin{array}{c}\text { Cell concentration } \\
\text { (times original cell dose) }\end{array}$ & CFU-C & CFU-DG & CFU.S \\
\hline 1 & $32 \pm 1$ & $0.8 \pm 0.5$ & 0 \\
2 & $66 \pm 3$ & $1.2 \pm 0.6$ & $1.5 \pm 1$ \\
3 & $160 \pm 4$ & $0.5 \pm 0.3$ & 0 \\
\hline
\end{tabular}

erythrocytes and their nucleated precursors, including CFU-E (Fig. 3). They are destroyed within $30 \mathrm{~s}$ of exposure to water. BFU-E is nearly as sensitive, disappearing in $1 \mathrm{~min}$. Murine CFU-S are somewhat more resistant; $2 \mathrm{~min}$ is required to totally destroy them (Fig. 3 ). The mouse CFU-DG fare slightly better than the CFU-S; for example, at the 1-min point $30 \%$ of the former and only $7 \%$ of the latter are detectable (Fig. 3). Comparison of the mouse and human CFU-DG curves (Figs. 3 and 5) reveals that they closely resemble each other, with the 1-, 2-, and 3-min points being nearly identical. Of the colony-forming units, both human and mouse CFU-C were clearly the most resistant to water treatment (Figs. 3 and 5). The morphologically recognizable cells were able to resist the hypotonic effect of water more successfully than CFU-S and CFU-DG. From the results obtained, one can conclude that during the maturation along the granulocytic line, cells acquire increased capability to tolerate hypo-osmolar conditions.

Decrease in colony-forming unit numbers as a result of exposure to water may not necessarily reflect direct effect on the precursor cells. Several workers have suggested that normal monocytoid cells $(15,16)$ and $T$ cells (17) may enhance erythropoiesis in vitro. Despite contradictory reports $(18,19)$, the possibility that hypotonicity in fact selectively destroyed the helper cells

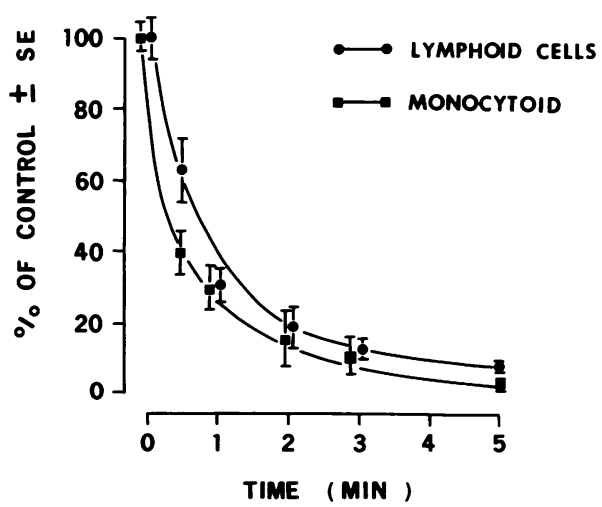

FigURE 4 Effect of hypotonic lysis on viable counts of mouse lung monocyte-macrophages and lymph node lymphocytes. Mean of three experiments. 


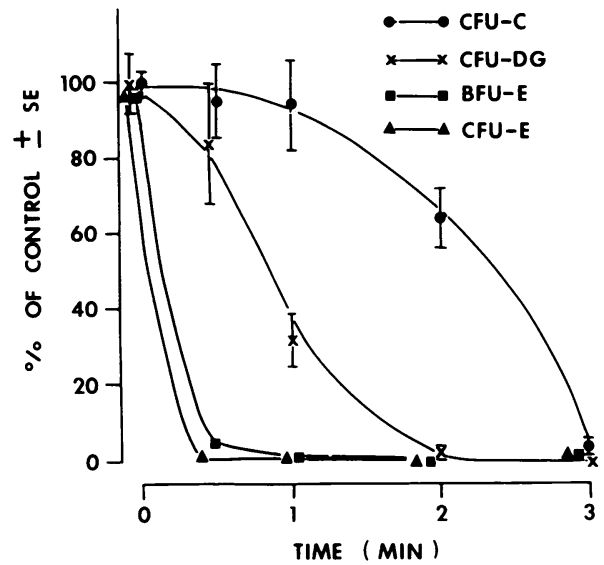

FIGURE 5 Effect of hypotonic lysis on human colony-forming units. Counts are based on three experiments. The original samples contained 196 CFU-C, 60 CFU-DG, 152 BFU-E, and $201 \mathrm{CFU}-\mathrm{E} / 4 \times 10^{5}$ cells. Each point is an average of 9-18 observations.

and as a result impaired colony formation could not be ignored. Therefore, in this study lysed bone marrow was cocultured with monocytoid cells and thymocytes in numbers equaling the loss of lipase-positive and theta-sensitive cells. Restoration of colony numbers did not occur with addition of these lymphoid or mononuclear phagocyte populations. Based on this evidence, we conclude that a variety of hematopoietic progenitor cells can be distinguished by differences in tolerance to hypotonicity.

In earlier works we have been able to show that the colonies formed both in diffusion chambers (CFU-DG) and in agar (CFU-C) consist of myeloid cells but are probably not expressions of the same precursor cell. The observations forming the basis of this conclusion were: (a) CFU-DG are formed much faster from cultured murine marrow than are CFU-C (8). (b) The human CFU-DG and CFU-C behave quite differently in an in vivo culture. The number of CFU-DG decreases progressively during a 4-d period, whereas the CFU-C decline initially then increase above the original inoculum number (20). In this work the distinctiveness of CFU-C and CFU-DG is supported by the observed differences in response to hypotonicity. Human (Fig. 5) and murine (Fig. 3) marrow exposed to hypotonic lysis for 2 and $3 \mathrm{~min}$, respectively, still contained a considerable number of CFU-C but formed no colonies on subsequent culture in diffusion chambers. On the other hand, in an earlier work (20) in most cases 2-d culture of human hemopoietic cells in vivo resulted in a cell suspension that gave rise to colonies in diffusion chambers (CFU-DG) but not in agar (CFU-C), this time suggesting that CFU-DG do not differentiate in agar.

Results from this and an earlier study (20) suggest that both human and murine CFU-DG are more primi- tive than CFU-C. Still unanswered remains the question of whether CFU-DG is an expression of differentiation of the pluripotent stem cell; i.e., is it identical with murine CFU-S or its human equivalent, or is it an intermediate stem cell that is not yet comitted to granulocytic differentiation. The cell separation techniques based on differences in cell size and density hopefully may help us to solve this problem.

Data displayed in Fig. 3 and Table I clearly indicate that we now have a simple and reproducible technique to obtain a population rich in CFU-C and devoid of other precursor cells. This certainly facilitates interpretation of results because the effect of efflux from an earlier compartment can be ignored.

\section{ACKNOWLEDGMENTS}

We are most grateful to Dr. Arne Bøyum for advice and to Miss Sharon Pitts for technical assistance.

This work was supported by U. S. Public Health Service grants CA 12800 , CA 15688, and CA 15619 , and by a contract with the Brown and Williamson Tobacco Corporation; Philip Morris, Incorporated; R. J. Reynolds Tobacco Company; and the United States Tobacco Company.

\section{REFERENCES}

1. Miller, R. G., and R. A. Phillips. 1969. Separation of cells by velocity sedimentation. J. Cell. Physiol. 73: 191-202.

2. Wells, J. R., G. Opelz, and M. J. Cline. 1977. Characterization of functionally distinct lymphoid and myeloid cells from human blood and bone marrow. II. Separation by velocity sedimentation.J. Immunol. Methods. 18: 79-93.

3. Bøyum, A. 1968. Separation of leukocytes from blood and bone marrow. Scand. J. Clin. Lab. Invest. 21(Suppl. 97): $1-9$.

4. Wells, J. R., G. Opelz, and M. J. Cline. 1977. Characterization of functionally distinct lymphoid and myeloid cells from human blood and bone marrow. I. Separation by a buoyant density gradient technique.J. Immunol. Methods. 18: 63-77.

5. Løvhaug, D., A. Bøyum, and T. Kristiansen. 1978. Culture of hemopoietic cells in diffusion chambers. In Hemopoietic Cell Differentiation (ICN-UCLA Symposia on Molecular and Cellular Biology, Vol. X). D. W. Golde, M. J. Cline, D. Metcalf, and C. F. Fox, editors. Academic Press, Inc., New York. 175- 192.

6. Willcox, M. B., D. W. Golde, and M. J. Cline. 1976. Cytochemical reactions of human hematopoietic cells in liquid culture. J. Histochem. Cytochem. 9: 979-983.

7. Till, J. E., and E. A. McCulloch. 1961. A direct measurement of the radiation sensitivity of normal mouse bone marrow cells. Radiat. Res. 14: 213-222.

8. Niskanen, E., and M. J. Cline. 1979. Growth of mouse and human bone marrow in diffusion chambers in mice. Development of myeloid and erythroid colonies and proliferation of myeloid stem cells in cyclophosphamide- and erythropoietin-treated mice.Cell Tissue Kinet. 11: 59-70.

9. Steinberg, H. N., E. S. Handler, and E. E. Handler. 1976. Assessment of erythrocytic and granulocytic colony formation in an in vivo plasma clot diffusion chamber culture system. Blood. 47: 1041-1057.

10. Pike, B. L., and W. A. Robinson. 1970. Human bone marrow colony growth in agar gel.J. Cell. Physiol. 76: 77-84.

11. Golde, D. W., and M. J. Cline. 1972. Identification of the 
colony-stimulating cell in human peripheral blood. $J$. Clin. Invest. 51: 2981-2983.

12. Sumner, M. A., T. R. Bradley, G. S. Hodgson, M. J. Cline, P. A. Fry, and L. Sutherland. 1972. The growth of bone marrow cells in liquid culture. Br. J. Haematol. 23: 221-234.

13. Iscove, N. N., F. Sieber, and K. H. Winterhalter. 1974. Erythroid colony formation in cultures of mouse and human bone marrow: analysis of the requirement for erythropoietin by gel filtration and affinity chromatography on agarose-concanavalin A. J. Cell. Physiol. 83: 309-320.

14. Golde, D. W., N. Bersch, and M. J. Cline. 1976. Potentiation of erythropoiesis in vitro by dexamethasone. J. Clin. Invest. 57: 57-62.

15. Aye, M. T. 1977. Erythroid colony formation in cultures of human marrow: effect of leukocyte-conditioned medium. J. Cell. Physiol. 91: 69-77.
16. Meyers, P. A., J. I. Kurland, and M. A. S. Moore. 1978. In vitro control of erythropoeisis by macrophages. Exp. Hematol. 6(Suppl. 3): 14. (Abstr.)

17. Nathan, D. G., L. Chess, D. G. Hillman, B. Clarke, J. Breard, E. Merler, and D. E. Housman. 1978. Human erythroid burst-forming unit: T cell measurement for proliferation in vitro. J. Exp. Med. 147: 324-338.

18. Rinehart, J. J., E. D. Zanjani, B. Nomdedeu, B. J. Gormus, and M. E. Kaplan. 1978. Cell-cell interactions in erythropoiesis. Role of human monocytes. J. Clin. Invest. 62: 979-986.

19. Nomdedeu, B., B. J. Gormus, J. J. Rinehart, M. E. Kaplan, and E. D. Zanjani. 1978. Are T lymphocytes required for growth and differentiation of human erythroid burst-forming units (BFU-E) in vitro? Blood. 52(Suppl. 1): 213. (Abstr.)

20. Niskanen, E., T. Olofsson, and M. Cline. 1979. Hemopoietic precursor cells in human peripheral blood. Am.J. Hematol. In press. 